\title{
A STUDY ON FINE NEEDLE ASPIRATION CYTOLOGY OF ENLARGED THYROID GLAND AND ITS CORRELATION WITH ANTI-TPO ANTIBODY LEVEL IN A TERTIARY CARE HOSPITAL OF EASTERN REGION OF INDIA
}

\author{
Gopinath Barui ${ }^{1}$, Manas Talukdar ${ }^{2}$, Kaberi Datta $^{3}$, Rupam Karmakar 4 \\ ${ }^{1}$ Associate Professor, Department of Pathology, R. G. Kar Medical College, Kolkata. \\ ${ }^{2}$ Demonstrator, Department of Laboratory Medicine, R. G. Kar Medical College, Kolkata. \\ ${ }_{3}^{3}$ Medical Officer, Department of Pathology, R. G. Kar Medical College, Kolkata. \\ 4Professor, Department of Pathology, Burdwan Medical College, Burdwan.
}

\begin{abstract}
BACKGROUND

Fine Needle Aspiration Cytology (FNAC) is a simple procedure to evaluate thyroid swelling. In addition to this, thyroid function tests and tests for auto-antibodies like Anti-Thyroid Peroxidase antibody (Anti-TPO) also play an important role to diagnose thyroid diseases. But there are a very few studies, which have focused on a combination of FNAC findings and anti-TPO level to evaluate thyroid swelling.

The aim of this study was to find out the correlation between FNAC findings and Anti-TPO antibody level in patients presenting with palpable thyroid swelling.
\end{abstract}

\section{MATERIALS AND METHODS}

This analytical observational study included 75 patients presenting with thyroid swelling without any history of thyroid related drug intake or surgery. The FNAC done by non-aspiration technique and findings were correlated with histopathology where surgical specimens were available, specially to confirm the diagnosis of follicular or papillary neoplasm. The anti-TPO antibody level was measured by microplate enzyme immunoassay.

\section{RESULTS}

Most of the non-neoplastic lesions were below 40 years of age. This study also revealed marked female preponderance (85.3\%), both in non-neoplastic (83.6\%) and neoplastic (88.2\%) group of thyroid lesions. Mean Anti-TPO antibody level (IU/mL) in autoimmune thyroiditis group including Hashimoto's thyroiditis and lymphocytic thyroiditis is 203; in other non-neoplastic group including colloid, thyrotoxic and adenomatoid goitre is 86 ; whereas in neoplastic group the level is 32.22 . Statistically, autoimmune thyroiditis group has significantly higher Anti-TPO level compared to other non-neoplastic group ( $\mathrm{p}=0.04)$ and neoplastic group ( $\mathrm{p}=0.01)$. But there is no significant difference of mean Anti-TPO level between neoplastic (value $32.22 \mathrm{IU} / \mathrm{mL}$ ) and overall non-neoplastic group (value $121.7 \mathrm{IU} / \mathrm{mL}$ ), as $\mathrm{p}$ value is 0.07 .

\section{CONCLUSION}

A high anti-TPO antibody level in autoimmune thyroiditis (Hashimoto's and lymphocytic thyroiditis) has got a definite clinical significance in addition to FNAC in context to diagnostic and therapeutic protocol, as both cases are immunological in origin. But Anti-TPO antibody level does not have any significant role in differentiating other non-neoplastic lesions like colloid and adenomatoid goitre from neoplastic lesions of thyroid gland.

\section{KEYWORDS}

Anti-TPO Antibody, Thyroid Gland Swelling, FNAC.

HOW TO CITE THIS ARTICLE: Barui G, Talukdar M, Datta K, et al. A study on fine needle aspiration cytology of enlarged thyroid gland and its correlation with anti-TPO antibody level in a tertiary care hospital of eastern region of India. J. Evolution Med. Dent. Sci. 2017;6(49):3772-3776, DOI: 10.14260/Jemds/2017/815

\section{BACKGROUND}

Thyroid gland is unique among the endocrine organs because of its superficial location, which enables early detection of any abnormality. The spectrum of thyroid diseases ranges from inflammatory, hyperplastic to neoplastic disorders. Thyroid lesions can present as diffuse or

Financial or Other, Competing Interest: None.

Submission 12-05-2017, Peer Review 06-06-2017,

Acceptance 12-06-2017, Published 19-06-2017.

Corresponding Author:

Dr. Manas Talukdar,

10/ 1, Girish Ghosh Street,

Kolkata-700108,

West Bengal.

E-mail: talukdarmanas09@gmail.com

DOI: $10.14260 /$ jemds $/ 2017 / 815$ nodular swellings and these can belong to any one of the following functional categories: Euthyroid, Hypothyroid or Hyperthyroid. Therefore, history and clinical examinations alone do not always reflect the exact nature of the swelling, particularly in cases of malignancy and autoimmune thyroiditis. Various other modalities of investigations like thyroid isotope scanning, radio-iodine uptake test, USG, CT, fluorescence scanning give a measure of the physiological and anatomical nature of the thyroid lesions, but fall far short of providing a pathological diagnosis. Moreover, these investigations are costly and far beyond the reach of the most poor patients. With this background, Fine Needle Aspiration Cytology (FNAC) findings and assay of serum Anti-Thyroid Peroxidase (anti-TPO) antibody have evolved as major components in the investigations of thyroid nodules and diffuse thyroid enlargement. 
The greatest merit of thyroid FNAC is the possibility to identify a substantial proportion of thyroid swelling as benign, and thus reduce unnecessary surgery of benign lesions.[1-5] Other examples of its clinical applications are in the diagnosis of autoimmune thyroiditis and of inoperable high-grade malignancies. Thyroid Peroxidase (TPO) is a glycoprotein enzyme located in the thyrocyte membrane, which catalyses oxidation reaction of iodine on tyrosine residue in thyroglobulin to yield triiodothyronine and thyroxin. Anti-TPO antibodies are cytotoxic and they damage the thyroid cells by different types of mechanisms like complement activation and antibody dependent cell cytotoxicity. In vast majority of Hashimoto patients, circulating autoantibodies against thyroid peroxidase is found. Previous researchers have proved that assays of Anti-TPO antibody have high specificity, sensitivity and accuracy to detect Hashimoto's Thyroiditis.[6] Detection of these antibodies in significant titre helps in establishing the aetiology of both hypo- and hyper-functioning thyroid disease. It is also found that the antibody titre vary among individuals depending on stage and activity of the underlying autoimmune process.

So considering all these facts, the present study highlights the correlation of FNAC of thyroid nodule and anti-TPO antibody in patients presented with enlarged thyroid gland in one of the tertiary care hospitals of Eastern Region of India.

\section{MATERIALS AND METHODS}

After obtaining approval from the Institutional Ethics Committee, this study was conducted in the Department of Pathology in collaboration with Department of Biochemistry of the same Institute over a period of one year.

It was an analytical observational study based on FNAC in diagnosing the different thyroid lesions and its correlation with Anti-TPO antibody including the both neoplastic and nonneoplastic disorders. Patients more than 20 years with a palpable thyroid swelling were selected as study population. Patients having history of thyroid related drug intake or any thyroid related surgery were excluded.

The samples were collected in the Department of Pathology by FNAC of enlarged thyroid gland and blood samples were collected in the Department of Biochemistry for measurement of anti-TPO antibody.

A non-aspiration needle puncture technique was used for superficial, easily accessible lesions. However, traditional biopsy technique using syringe (with 22- or 23-gauge needle) and a pistol was used in case of inadequate material yield by the non-aspiration technique. An FNAC material was stained by Leishman-Giemsa and Papanicolaou stain, and slides were examined under binocular light microscope (Olympus $\mathrm{CH} 20 \mathrm{i}$ ). The FNAC findings were correlated with histopathology reports, where surgical specimens were available specially to confirm the diagnosis of follicular or papillary neoplasm.

In the present study, quantitative determination of Thyroid Peroxidase (TPO) autoantibodies in human serum or plasma was done by a microplate enzyme immunoassay as it is highly specific, highly sensitive and less costly.

Depending on cytological findings (along with histopathology where possible), the thyroid lesions were categorised and the Anti-TPO antibody levels were compared statistically by unpaired ' $t$ ' test to find out its significance in categorising different thyroid lesions in adjunct to FNAC, ( $p$ value $<0.05$ was considered as significant). To find out the significance of age group between neoplastic and nonneoplastic thyroid lesions, Chi-square test was applied.

\section{RESULTS}

In the present study, FNAC was carried out on 75 patients with clinically palpable thyroid swelling and at the same time serum Anti-TPO antibody levels were measured from serum of all those patients. However, histopathological confirmation was possible only with the cases where surgical specimens were present, especially in all neoplastic lesions and a few cases of non-neoplastic lesions.

Table 1 shows the different types of thyroid lesions of all categories included in our study, their percentage of occurrence and mean titre of anti-TPO antibody level.

This study shows that most of the non-neoplastic lesions were distributed in the age group of 40 yrs. and below. Neoplastic lesions were more common among above 40 years' age group. When the observations were subjected to Chisquare test, a significant association was noted between the types of thyroid lesions (non-neoplastic/neoplastic) and their age distribution ( $\mathrm{P}=0.0012$ ) (Table 2).

This study also revealed marked female preponderance (85.3\%), both in non-neoplastic (83.6\%) and neoplastic (88.2\%) thyroid lesions (Table 3).

Regarding the anti-TPO antibody level, the mean ( \pm SD) value in overall non-neoplastic and neoplastic group were $121.7 \pm 200.19 \mathrm{IU} / \mathrm{mL}$ and $32.22 \pm 22.76$ respectively and $\mathrm{p}$ value is 0.07 which is not statistically significant (Table 4).

However, if we compare Anti-TPO antibody level between Autoimmune thyroiditis including Hashimoto's and lymphocytic thyroiditis (mean \pm SD is $203 \pm 262 \mathrm{IU} / \mathrm{mL}$ ) with other non-neoplastic goitre including colloid goitre, adenomatoid goitre and thyrotoxic goitre (mean \pm SD is $86 \pm$ $157 \mathrm{IU} / \mathrm{mL}$ ), we find Anti-TPO antibody level is significantly higher in the Autoimmune thyroiditis group ( $\mathrm{p}$ value $=0.04$ ) (Table 5).

Similarly, while comparing with neoplastic group, AntiTPO antibody level is significantly higher in autoimmune thyroiditis group than neoplastic group, $(\mathrm{P}$ value= 0.01$)$ (Table 6).

\begin{tabular}{|c|c|c|c|c|}
\hline $\begin{array}{c}\text { Broad } \\
\text { Category }\end{array}$ & $\begin{array}{l}\text { Type of } \\
\text { Lesion }\end{array}$ & $\begin{array}{l}\text { No. } \\
\text { Total } \\
\mathrm{n}=75\end{array}$ & (\%) & $\begin{array}{c}\text { Mean Anti- } \\
\text { TPO Antibody } \\
\text { Level } \\
\text { (IU/mL) } \\
\text { (mean } \pm \text { SD) }\end{array}$ \\
\hline \multirow{3}{*}{$\begin{array}{l}\text { Other Non- } \\
\text { neoplastic } \\
\text { group }\end{array}$} & Colloid goitre & 19 & 25.33 & \multirow{3}{*}{$86 \pm 157$} \\
\hline & $\begin{array}{c}\text { Adenomatoid } \\
\text { goitre }\end{array}$ & 9 & 12 & \\
\hline & Thyrotoxic goitre & 9 & 12 & \\
\hline \multirow{2}{*}{$\begin{array}{l}\text { Non- } \\
\text { neoplastic } \\
\text { Thyroiditis } \\
\text { group }\end{array}$} & \begin{tabular}{|c|}
$\begin{array}{c}\text { Hashimoto's } \\
\text { thyroiditis }\end{array}$ \\
\end{tabular} & 11 & 14.67 & \multirow[b]{2}{*}{$203 \pm 262$} \\
\hline & $\begin{array}{c}\text { Florid } \\
\text { lymphocytic } \\
\text { thyroiditis }\end{array}$ & 7 & 9.34 & \\
\hline \multirow{3}{*}{$\begin{array}{l}\text { Neoplastic } \\
\text { group }\end{array}$} & $\begin{array}{c}\text { Papillary } \\
\text { carcinoma } \\
\text { thyroid }\end{array}$ & 9 & 12 & \multirow{3}{*}{$32.22 \pm 22.76$} \\
\hline & $\begin{array}{l}\text { Follicular } \\
\text { neoplasm }\end{array}$ & 6 & 8 & \\
\hline & $\begin{array}{c}\text { Medullary } \\
\text { carcinoma } \\
\text { thyroid }\end{array}$ & 1 & 1.33 & \\
\hline
\end{tabular}




\begin{tabular}{|c|c|c|c|c|}
\hline & $\begin{array}{c}\text { Anaplastic } \\
\text { carcinoma } \\
\text { thyroid }\end{array}$ & 1 & 1.33 & \\
\hline Unsatisfactory & Unsatisfactory & 3 & 4 & NA \\
\hline Table 1. Thyroid Lesions diagnosed by FNAC and their \\
Mean Anti-TPO Antibody Level
\end{tabular}

\begin{tabular}{|c|c|c|c|c|}
\hline $\begin{array}{c}\text { Age } \\
\text { Group }\end{array}$ & $\begin{array}{c}\text { Non- } \\
\text { Neoplastic }\end{array}$ & Neoplastic & Inconclusive & Total (\%) \\
\hline $\begin{array}{c}20-40 \\
\text { yrs. }\end{array}$ & 40 & 5 & 3 & $48(64 \%)$ \\
\hline$>40$ yrs. & 15 & 12 & 0 & $27(36 \%)$ \\
\hline Total & 55 & 17 & 3 & $75(100 \%)$ \\
\hline \multicolumn{5}{|c|}{ Table 2. Age Distribution of Thyroid } \\
Lesions in Present Study \\
\hline
\end{tabular}

Pearson chi-square score- $10.39(\mathrm{df}=1), \mathrm{P}=0.0012$ (excluding inconclusive lesions).

\begin{tabular}{|c|c|c|c|}
\hline Type of Lesions & Male (\%) & Female (\%) & Total \\
\hline Non-neoplastic & $9(16.3)$ & $46(83.6)$ & 55 \\
\hline Neoplastic & $2(11.7 \%)$ & $15(88.2)$ & 17 \\
\hline Inconclusive & 0 & 3 & 3 \\
\hline Total (\%) & $\mathbf{1 1}(14.6)$ & $\mathbf{6 4}(85.3)$ & $\mathbf{7 5}$ \\
\hline \multicolumn{2}{|c|}{ Table 3. Sex Distribution of Thyroid Lesions } \\
in the Present Study \\
\hline
\end{tabular}

\begin{tabular}{|c|c|c|c|}
\hline $\begin{array}{c}\text { Study } \\
\text { Parameter }\end{array}$ & $\begin{array}{c}\text { All Non-Neoplastic Group } \\
\text { (Autoimmune Thyroiditis } \\
\text { and other Non-Neoplastic } \\
\text { Lesions) }\end{array}$ & $\begin{array}{c}\text { Neoplastic } \\
\text { Group }\end{array}$ & $\begin{array}{c}\text { P } \\
\text { value }\end{array}$ \\
\hline $\begin{array}{c}\text { Anti-TPO } \\
\text { antibody } \\
\text { (IU/mL) } \\
\text { (mean } \pm \text { SD) }\end{array}$ & $121.7 \pm 200.19$ & $\begin{array}{c}32.22 \pm \\
22.76\end{array}$ & 0.07 \\
\hline \multicolumn{2}{|c|}{ Table 4. Comparison of Anti-TPO Level between all Non- } \\
Neoplastic Group and Neoplastic Group \\
\hline
\end{tabular}

\begin{tabular}{|c|c|c|c|}
\hline $\begin{array}{c}\text { Study } \\
\text { Parameter }\end{array}$ & $\begin{array}{c}\text { Autoimmune } \\
\text { Thyroiditis } \\
\text { Group } \\
\text { (Hashimoto's and } \\
\text { Lymphocytic) }\end{array}$ & $\begin{array}{c}\text { Other Non- } \\
\text { Neoplastic Group } \\
\text { (Colloid Goitre, } \\
\text { Adenomatoid } \\
\text { Goitre and } \\
\text { Thyrotoxic } \\
\text { Goitre) }\end{array}$ & P value \\
\hline $\begin{array}{c}\text { Anti-TPO } \\
\text { Antibody } \\
\text { IIU/mL) } \\
\text { (mean } \pm \text { SD) }\end{array}$ & $203 \pm 262$ & $86 \pm 157$ & 0.04 \\
\hline $\begin{array}{c}\text { Table 5. Comparison of Anti-TPO Level between } \\
\text { Autoimmune Thyroiditis Group and other Non-Neoplastic } \\
\text { Group }\end{array}$ & \multicolumn{4}{|c|}{} \\
\hline
\end{tabular}

\begin{tabular}{|c|c|c|c|}
\hline $\begin{array}{c}\text { Study } \\
\text { Parameter }\end{array}$ & $\begin{array}{c}\text { Autoimmune } \\
\text { Thyroiditis } \\
\text { (Hashimoto's and } \\
\text { Lymphocytic } \\
\text { Thyroiditis) }\end{array}$ & $\begin{array}{c}\text { Neoplastic Group } \\
\text { (Follicular Neoplasm, } \\
\text { Papillary, Medullary } \\
\text { and Anaplastic } \\
\text { Carcinoma) }\end{array}$ & P value \\
\hline $\begin{array}{c}\text { Anti-TPO } \\
\text { (IU/mL) } \\
\text { (mean } \pm \\
\text { SD) }\end{array}$ & $203 \pm 262$ & $32.22 \pm 22.76$ & 0.01 \\
\hline $\begin{array}{c}\text { Table 6. Comparison of Anti-TPO Antibody Level between } \\
\text { Autoimmune Thyroiditis Group and Neoplastic Group }\end{array}$ \\
\hline
\end{tabular}

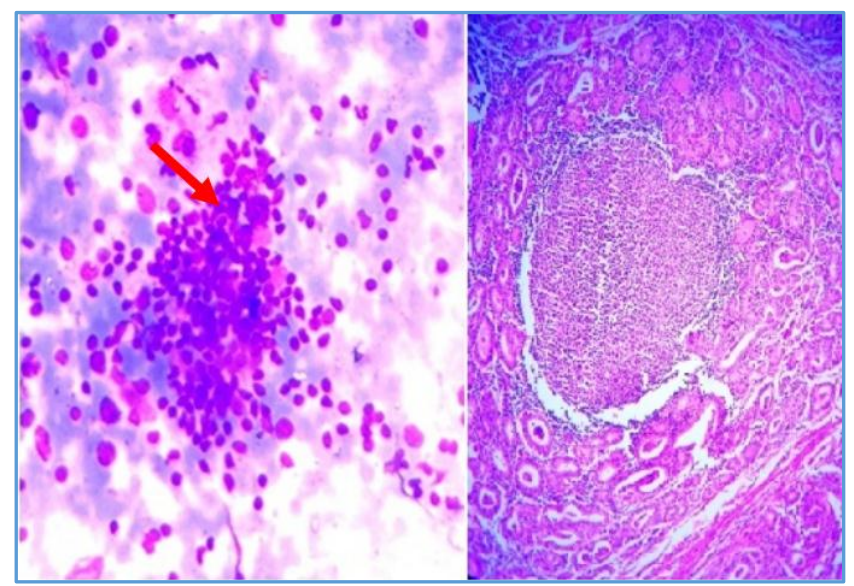

Figure 1. (Left) Cytosmear showing (arrow) Lymphocytes Impinging on Thyroid Follicular Cells suggestive of

Follicular Destruction in a Case of Hashimoto's Thyroiditis (400X Leishman-Giemsa stain); (Right) Histopathological Section of same case of Hashimoto's Thyroiditis (100X, H and E stain)

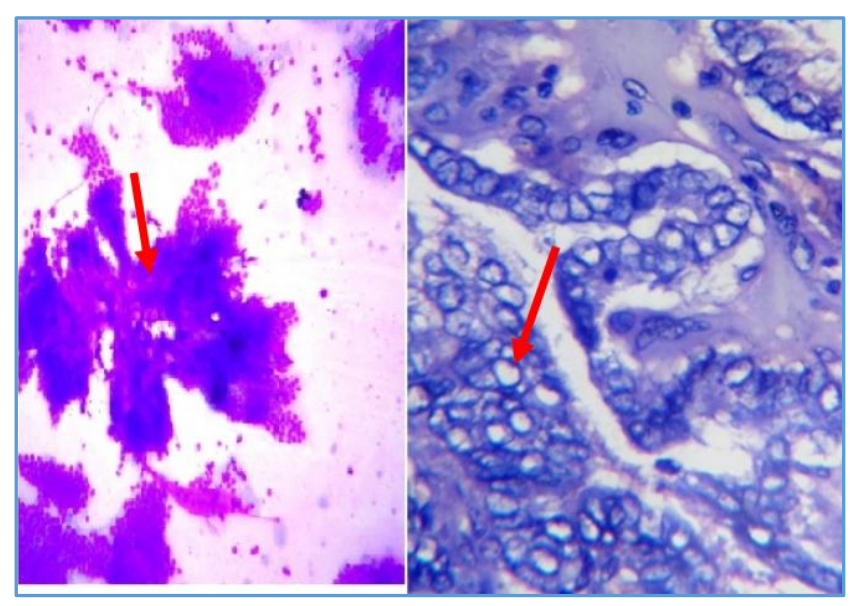

Figure 2. (Left) Cytological Feature of Papillary Carcinoma of Thyroid showing (Arrow) Large Papillary Fragments (Leishman-Giemsa stain, $400 \mathrm{X}$ ); (Right) Histopathological Picture of Same Case of Papillary Carcinoma Thyroid showing (Arrow) Nuclear Overlapping and Ground Glass Nuclei (400X, H and E stain)

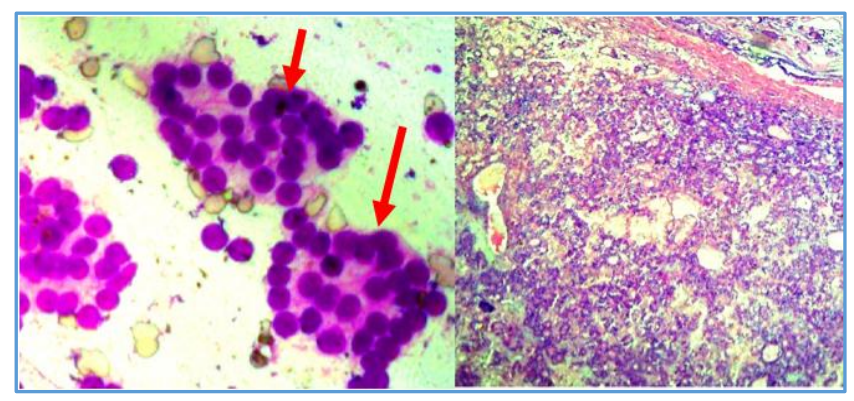

Figure 3. (Left)- Cytosmear of Follicular Neoplasm showing (Arrow) Repetitive Follicles (400X, Leishman-Giemsa Stain); (Right)- Histological Photograph of same case showing Features of Follicular Adenoma (100X, $\mathrm{H}$ and E stain) 


\section{DISCUSSION}

Being a cost-effective and simple minimally invasive procedure, Fine Needle Aspiration Cytology is considered as a first-line investigation for management of thyroid swelling along with other ancillary tests including various biochemical parameters. In the present study, FNAC was carried out on 75 patients with clinically palpable thyroid swellings and findings were correlated with histopathological reports where possible and with anti-TPO antibody level in all cases. All the neoplastic lesions diagnosed by FNAC were confirmed by histopathological reports.

The current study reveals that the age of the patient at the time of diagnosis is an important prognostic factor. Though thyroid neoplastic lesions are most common between 50 - 60 years' age group, majority of the patients with thyroid lesions (including both neoplastic and non-neoplastic) are between 20 and 50 years. This observation is compatible with the work done by Mandrekar et al and Saha et al.[7,8]

The sex distribution of thyroid lesions in the present study shows a remarkable female preponderance, both in the nonneoplastic and neoplastic category. A male-to-female ratio in the present study is 1:5.81, whereas Mandrekar et al reported this ratio to be 1: 6.1.[7]

In the present study based on FNAC findings, thyroid lesions were divided broadly into four groups- non-neoplastic autoimmune thyroiditis (Hashimoto and Lymphocytic), other non-neoplastic (including adenomatoid, colloid and thyrotoxic goitre), neoplastic (including follicular neoplasm and other malignant thyroid tumours) and unsatisfactory. Out of 75 thyroid lesions, overall non-neoplastic (including thyroiditis and other non-neoplastic lesions), neoplastic and unsatisfactory smears were $73.34 \%, 22.66 \%$ and $4.0 \%$ respectively. The patients between 20 - 40 years' age group were the most commonly (64\%) affected group and benign lesions are predominant. Similar results were reported by Lakshmi S et al, who studied 251 patients with thyroid swelling. ${ }^{[9]}$ The commonest age group affected were $21-30$ years $(28.68 \%)$ and 31 - 40 years $(25.09 \%)$ with preponderance of benign lesions. This was supported by Sachin A Badge et al, who found 54\% of the patients in $20-40$ years' age group.[10]

Most $(63.1 \%)$ of the colloid goitre cases presented with diffuse swelling without any significant rise in anti-TPO antibody level.

Eleven cases were diagnosed as Hashimoto's thyroiditis (Figure 1) and 7 cases as lymphocytic thyroiditis by FNAC. Most of the affected patients were female and with high antiTPO antibody level with mean \pm SD is $203 \pm 262 \mathrm{IU} / \mathrm{mL}$.

Regarding the anti-TPO level, Engler $\mathrm{H}$ et al[11] showed that elevated anti-TPO antibody level $>500 \mathrm{IU} / \mathrm{mL}$ were found in > $59 \%$ of autoimmune thyroiditis cases, but in none of the other thyroid and non-thyroid diseases. According to them, highest (88\%) frequency of positive results was obtained in autoimmune hypothyroidism (Hashimoto's thyroiditis) with a cut-off value of $200 \mathrm{IU} / \mathrm{mL}$. Sensitivity of $96 \%$ was obtained for Hashimoto's thyroiditis.

In a retrospective cross-sectional study on 74 subjects, Jeena EJ et al concluded that Anti-TPO antibody estimation is a very useful test to diagnose autoimmune thyroiditis.[12]

Iddah MA and Macharia BN stated in their article that antiTPO autoantibodies are found in over $90 \%$ of patients with autoimmune hypothyroidism and Graves' disease.[13] Our study also supports these findings where we proved significant increase in Anti-TPO level in cases of autoimmune thyroiditis group (Hashimoto's and Lymphocytic) comparing to colloid/adenomatoid goitre and neoplastic lesions.

Among 17 neoplastic lesions, papillary carcinoma thyroid (Figure 2) was the commonest malignant tumour (9 out of 17 cases of neoplastic thyroid lesions, $52.9 \%$ of the neoplastic lesions). Next common neoplastic lesion was (6 out of 17 cases) follicular neoplasm (Figure 3). Neoplastic lesions were mostly $(82.3 \%)$ nodular in type. The anti-TPO antibody level in neoplastic group was significantly lower compared to autoimmune thyroiditis group. However, Swati Bera et al observed in their study that most of the colloid goitre cases were euthyroid and anti-TPO antibody level was high in papillary carcinoma of thyroid.[14] They noted increased antiTPO antibody level in multinodular goitre, also which is contradictory to our findings. No significant increase in the level of the anti-TPO antibody was seen in follicular neoplasm (Follicular adenoma and Follicular carcinoma) in their study. They suggested that immunological basis in the development of papillary carcinoma may be considered as a promising field of study. However, the present study could not find any significant role of Anti-TPO antibody level to differentiate neoplastic and non-neoplastic lesions of thyroid gland, which is supported by the study of Yalcin S et al.[15] In another retrospective study, Paparodis $\mathrm{R}$ et al concluded that high antiTPO antibody level might be protective against development of carcinoma in Hashimoto's thyroiditis patients.[16] For further clarification on role of anti-TPO antibody level in thyroid cancers, especially papillary carcinoma in background of autoimmune thyroiditis a longitudinal study on larger sample size is required to be done in different stages of the disease.

\section{CONCLUSION}

This hospital-based analytical, observational study showed that thyroid disorders are predominantly found in females. About the age, we can conclude that non-neoplastic thyroid disorders are noted predominantly below 40 years' age group and neoplastic disorders are mostly found between mostly 40 and 70 years' age group.

Most of the non-neoplastic lesions including both autoimmune thyroiditis and goitre were diffuse, whereas neoplastic lesions were usually nodular. Among nonneoplastic lesions, colloid goitre was the commonest lesion noted in our study.

This study showed that high anti-TPO antibody level in autoimmune thyroiditis is an important biochemical marker both from diagnostic and therapeutic point of view in addition to FNAC and can be used as an adjunct parameter for the diagnosis of autoimmune thyroiditis (Hashimoto's thyroiditis and lymphocytic thyroiditis). Anti-TPO antibody level is of little value in diagnosing and differentiating neoplastic lesions from other non-neoplastic lesions like colloid, adenomatoid goitre and thyrotoxic goitre.

However, there were certain limitations to this study. Firstly, histopathological correlation and confirmation was done in all neoplastic lesions; but in cases of non-neoplastic lesions like Hashimoto's thyroiditis, adenomatoid goitre, etc., this correlation was possible only where surgical indications were present and accordingly specimens were available. Secondly, other high-ended investigations like thyroid scan, 
molecular marker, etc. could not be possible in our settings for most of the cases. And finally a longitudinal study with larger sample size may provide some additional findings, especially regarding stages of autoimmune thyroiditis and its relation with Anti-TPO antibody level.

\section{REFERENCES}

[1] Hamburger JI, Husain M, Nishiyama R, et al. Increasing the accuracy of fine-needle biopsy for thyroid nodules. Arch Pathol Lab Med 1989;113(9):1035-41.

[2] Persson PS. Cytodiagnosis of thyroiditis. A comparative study of cytological, histological, immunological and clinical findings in thyroiditis, particularly in diffuse lymphoid thyroiditis. Acta Med Scand Suppl 1968;483:7-100.

[3] Crockford PM, Bain GO. Fine needle aspiration biopsy of the thyroid. Can Med Assoc J 1974;110(9):1029-32.

[4] McKee G. The role of fine needle aspiration cytology in the diagnosis of thyroid lesions. J R Soc Med 1998;91(Suppl 33):28-32.

[5] Muratli A, Erdogan N, Sevim S, et al. Diagnostic efficacy and importance of fine-needle aspiration cytology of thyroid nodules. J Cytol 2014;31(2):73-8.

[6] Yadav DK, Yadav R. Hashimoto's thyroiditis- diagnostic accuracy of antimicrosomal antibodies. Int J Sci Stud 2016;4(9):34-8.

[7] Mandreker SR, Nadkarni NS, Pinto RG, et al. Role of FNAC as the initial modality in the investigation of thyroid lesions. Acta Cytol 1995;39(5):898-904.

[8] Saha S, Mukherje S, Basu A, et al. Study of clinical profile of non-toxic goiter with special reference to correlation of pathology, lipid profile and antibody level. Journal of Evolution of Medical and Dental Sciences 2014;3(4):827-34.
[9] Lakshmi S, Latha B, Nirmala C. Spectrum of thyroid lesions on fine needle aspiration cytology. J International Medicine and Dentistry 2015;2(1): 53-62.

[10] Badge SA, Ovhal AG, Azad K, et al. Study of fine-needle aspiration cytology of thyroid lesions in rural area of Bastar district, Chhattisgarh. Int J Health Sci Res 2016;6(11):73-9.

[11] Engler H, Riesen WF, Keller B. Anti-thyroid peroxidase (anti-TPO) antibodies in thyroid diseases, nonthyroidal illness and controls. Clinical validity of a new commercial method for detection of anti-TPO (thyroid microsomal) autoantibodies. Clin Chim Acta 1994;225(2):123-36.

[12] Jeena EJ, Malathi M, Sudeep K. A hospital-based study of anti-TPO titer in patients with thyroid disease. Muller Journal of Medical Sciences and Research 2013;4(2):74-7.

[13] Iddah MA, Macharia BN. Autoimmune thyroid disorders. ISRN Endocrinol Article ID 509764, 2013;2013: p. 9.

[14] Bera S, Gupta S, Dutta KS, et al. Anti-thyroid peroxidise antibody level in thyroid nodules: with special reference to thyroid neoplasia. Int Res J Pharm 2013;4(6):150-2.

[15] Yalcin S, Ulger BV, Parlak 0 , et al. The role of preoperative serum thyroglobulin and thyroid autoantibody levels before histopathological diagnosis of thyroid cancers. Turk J Med Sci 2011;41(3):487-93.

[16] Paparodis $R$, Imam S, Todorova-Koteva $K$, et al. Hashimoto's thyroiditis pathology and risk for thyroid cancer. Thyroid 2014;24(7):1107-14. 